\title{
The Influence of the Environment on the Content of Macro- and Microelements in the Tanacetum vulgare
}

\author{
Marcin Konieczny ${ }^{1}$, Ewelina Ślęzak ${ }^{2}$ \\ 1 Independent Department of Biotechnology and Molecular Biology ${ }_{L}$ University of Opole, ul. K. Kominka 6A, \\ 45-035 Opole, Poland \\ 2 Institute of Ceramics and Building Materials in Opole, ul. Oświęcimska 21, 45-641 Opole, Poland \\ * Corresponding author's e-mail: 104949@uni.opole.pl
}

\begin{abstract}
Tansy (Tanacetum vulgare L.) grows in moderate area of the northern hemisphere, in Poland - its range covers the whole country. It appears on the farm wastelands, by roadsides, on enbankments, river banks, forest lips and in open spaces. The present paper has faced the challenge of defining the influence of the environmental conditions on the mineral composition of Tanacetum vulgare leaves. The plants were picked in the blooming period from May to September 2017 in 12 natural environments of their growth and at different contamination levels. The dried and minced plant material was submitted to chemical analyses of the bio elements content ( $\mathrm{K}, \mathrm{P}, \mathrm{Cu}, \mathrm{Zn}, \mathrm{Mo})$ of leaves. A great variety was observed when speaking in terms of particular elements content in dependence on the position. In all tests, significant quantities of $\mathrm{K}$ and $\mathrm{P}$ were found. The study results point at the very fact that the mineral composition of Tanacetum vulgare leaves is influenced by the environmental contamination, caused by the nearby "neighbourhood" of circulation areas of high traffic volume, factories or patrol stations.
\end{abstract}

Keywords: Tanacetum vulgare L., mineral components of plants, the anthropogenic areas, non-anthropogenic areas, environment.

\section{INTRODUCTION}

Tansy (Tanacetum vulgare L.) is a multiannual, aromatic plant which belongs to the Asteraceae. Family [Jakobs and Müller 2018, Goudarzi et al. 2015, Wolf et al. 2012, Qi et al. 2018], that incorporates about 200 species [Özbilgin et al. 2018]. This particular species originates from Eurasia from where it was introduced to North America, and subsequently naturalised [Mitich 1992]. At present, Tanacetum vulgare appears in moderate area of the northern hemisphere [Derda et al. 2012], in Poland - its range covers the whole country [Anna Ewa Wojciechowska 2008]. It grows on the farm wastelands, by roadsides, on enbankments, river banks, forest lips and in open spaces. [Kęsik, Wojciechowska, Pi'tura 2008, Mehrparvar et al. 2018]. Tanacetum vulgare is commonly known under the "Tansy" name, coming from a Greek word "athanasia" that means "immortality" which probably comes from the fact that its blooms do not wither [Aranđelović et al. 2017].

The plants of of Tanacetum type are rich in essential oils (EO). Due to the presence of thujones, the oils from Tacetum have been used in the traditional medicine dating from the ancient times [Moricz et al. 2015]. The content of thujones undergoes significant changes depending on the region where the plant grows as well as on the process of its drying [Aranđelović et al. 2017, Blagojevic et al. 2015]. Some chemotypes Tanacetum vulgare do not contain any toxic $\beta$-thujone [Héthelyi et al. 1981]. The changes in the thujone content in the tansy herbs were causing numerous problems in the folk medicine, including mistakes in the choice of an appropriate dose for making extracts. Such mistakes lead to excessive thujone consumption, which then resulted in the occurrence of many afflictions, both 
in case of children and adults [Halicioglu et al. 2011]. The present analytical technology allowed for the production techniques standardization, thanks to which the problem with thujone level in extracts was eliminated.

Nowadays, Tansy is commonly used as a component in lotions, cosmetics, dyes, ovicides, medicines and preservatives. Plant-based extracts are widely used in the present medicine in treating rheumatism, ulcers, fever and digestion disorders [Aranđelović et al. 2017]. In the traditional Russian medicine, the infusion from Tanacetum vulgare blooms is used for such medical purposes as quickening the process of wounds healing, the appetite improvement and as a painkiller [Zaurov et al. 2013].

Plants play the role of carriers which transport the chemical elements coming from water, air and mainly from soil to the animal and human organisms. Some heavy metals are necessary microelements for all plants; nevertheless, their high concentration is dangerous for the life and correct functioning of plants [Marques et al. 2009, White and Brown 2010]. Plant species gather different amounts of heavy metals in the surface organs and roots [Kashin and Ubugunov 2012, Motuzova et al. 2014]. A magnificent role in the metals accumulation is played by the morphology of surface organs, namely the leaves. The quantity of the accumulated heavy metals on the leaf surface depends on its size, presence of pilus, resin and wax on the surface. Metals locked in a wax tarnish are not scoured by water [Chaplygin et al. 2018].

Morphologically, the tansy (Tanacetum vulgare L.) shows certain differences between particular geographical regions. Its height ranges from 30 to $150 \mathrm{~cm}$; the stem has an arboreal form, more or less branchy, the leaves are feathered and bracken-like [Goudarzi et al. 2015]. Yellow blooms of a button shape create umbelliferous inflorescences on the plant top.

The aim of the paper was to compare the content of $\mathrm{K}, \mathrm{P} \mathrm{Cu}, \mathrm{Zn}$, Mo in the leaves of Tanacetum vulgare species belonging to the Asteraceae family that grows in spheres of different urbanization levels in the area of Poland.

\section{MATERIAL AND METHODS}

The tests of tansy (Tanacetum vulgare L.) were conducted in the blooming period from May to September 2017 in 12 natural environments of their growth (Table 1). Four out of twelve locations were in the anthropogenic areas (A), namely in the nearby the circulation areas of high traffic volume or close to institutions dealing with aluminium wheels casting and next to petrol stations. The other eight locations concerned non-anthropogenic areas $(\mathrm{N})$ - which means - grasslands in the distance of more than $200 \mathrm{~m}$ from not too busy roads, river banks, parks on the suburbs.

The collected leaves were dried for five days at room temperature, in a dark place, of increased air circulation. Secondly, the dried tansy was minced in a ball mill. The achieved material was later passed through a sieve of the mesh diameter $1 \mathrm{~mm}$ and it was stored in hermetically closed containers until the analysis time. The content of heavy metals was marked with the mass spectrometry method using ICP-MS apparatus after microwave wet mineralisation with aqua regia in the Mars-X apparatus.

Table 1. Locations of tansy samples collection (Tanacetum vulgare L.) in Poland with the division into anthropogenic (A) and non-anthropogenic $(\mathrm{N})$

\begin{tabular}{|c|l|c|c|c|}
\hline \multirow{2}{*}{ Lp. Location } & \multirow{2}{*}{ Geographical coordinates } & \multirow{2}{*}{ Type of area } \\
\cline { 3 - 4 } & & latitude $(\mathrm{N})$ & longitude $(\mathrm{E})$ & $\mathrm{N}$ \\
\hline 1 & Słubice & 52.33226 & 14.62062 & $\mathrm{~A}$ \\
\hline 2 & Szklarska Poręba & 50.82014 & 15.43838 & $\mathrm{~N}$ \\
\hline 3 & Kraśnik Dolny & 51.31680 & 15.59713 & $\mathrm{~N}$ \\
\hline 4 & Międzychód & 52.61319 & 15.90543 & $\mathrm{~N}$ \\
\hline 5 & Kudowa Zdrój & 50.43530 & 16.22743 & $\mathrm{~N}$ \\
\hline 6 & Żmigród & 51.48086 & 16.91363 & $\mathrm{~N}$ \\
\hline 7 & Pobiedziska & 52.46613 & 17.28842 & $\mathrm{~N}$ \\
\hline 8 & Łączki & 50.23020 & 17.19177 & $\mathrm{~A}$ \\
\hline 9 & Stanowice & 50.13162 & 18.68082 & $\mathrm{~N}$ \\
\hline 10 & Białka Tatrzańska & 49.23208 & 20.06148 & $\mathrm{~A}$ \\
\hline 11 & Starachowice & 51.05880 & 21.06459 & $\mathrm{~A}$ \\
\hline 12 & Stalowa Wola & 50.54976 & 22.07053 & \\
\hline
\end{tabular}




\section{RESULTS AND DISCUSSION}

The results of chemical composition analysis of Tanacetum vulgare leaves points at high differentiation of $\mathrm{K}, \mathrm{P}, \mathrm{Cu}, \mathrm{Zn}$, Mo contents.

The potassium content in the tansy leaves was changing depending on its position and was from $2.07 \%$ d.m. in Stubice to $3.2 \%$ d.m. in Starachowice (Fig. 1). The studies of Grela and Dzida [2001] showed that in a dry mass of herbs Tanacetum vulgare the potassium content was from 0.65 to $0.71 \%$ d.m.; however, Wierzchowska-Renke and others [1997] provide higher contents of this element, namely from 2.54 to $3.77 \%$ d.m.

The phosphorus content in the leaves ranged from $0.26 \%$ d.m. in Laczki to $0.68 \%$ d.m. in Międzychodzie (Fig. 2). In the studies by Wojciechowska [2008], the phosphorus content was between $0.15-0.45 \%$ d.m. The fact of phosphorus content increase in a dry mass of Tanacetum vulgare herbs can be explained by the studies from the year 1982. There, Lityński and Jurkowska proved that in the soils with the $\mathrm{pH}$ smaller than 5.5 and higher than 7.0, phosphorus undergoes a kind of regress which makes it unavailable for plants.

In the case of the $\mathrm{Cu}$ content in Tanacetum vulgare leaves, the results can be divided into two groups, of high and low $\mathrm{Cu}$ concentration. In the first, group there were 7 locations in which the metal concentration was oscillating from 10.86 to $15 \mathrm{mg} \cdot \mathrm{kg}^{-1} \mathrm{~d} . \mathrm{m}$. The second group was constituted by 5 locations of $\mathrm{Cu}$ concentration from 20.99 to $29.68 \mathrm{mg} \cdot \mathrm{kg}^{-1} \mathrm{~d} . \mathrm{m}$. A "measurement gap" appeared between these two groups in the form of results lack from 15 to $20 \mathrm{mg} \cdot \mathrm{kg}^{-1} \mathrm{~d}$.m. (Fig. 3).

While analyzing the state of natural environment around the mine and power plant of
Bełchatów, Jasion and others [2013] showed that the content of $\mathrm{Cu}$ in the Tanacetum vulgare leaves was from 11.90 to $16.8 \mathrm{mg} \cdot \mathrm{kg}^{-1} \mathrm{~d}$.m. Adamcova and others [2017] obtained different results, while they were comparing the metal contents in Tanacetum vulgare on the positions around a landfill site, in a closed part of the landfill and in soil that had contact with wastes. The results achieved by them point at the changes in the $\mathrm{Cu}$ content in the Tanacetum vulgare biomass depending on their location. On an area of the landfill and its neighbourhood, the copper content was $17.91 \mathrm{mg} \cdot \mathrm{kg}^{-1} \mathrm{~d} . \mathrm{m}$. in a closed part of the landfill and $62.86 \mathrm{mg} \cdot \mathrm{kg}^{-1} \mathrm{~d} . \mathrm{m}$. on the area surrounding the landfill. All the results show the influence that the vicinity of landfills can have on the $\mathrm{Cu}$ content in the plants biomass.

The $\mathrm{Zn}$ content in the Tanacetum vulgare leaves was diversified in all the studied areas (Fig. 3). In 7 locations, the $\mathrm{Zn}$ concentration did not exceed $100 \mathrm{mg} \cdot \mathrm{kg}^{-1} \mathrm{~d} . \mathrm{m}$, the smallest concentration of this metal was observed in Łączki, where it reached $28,846 \mathrm{mg} \cdot \mathrm{kg}^{-1} \mathrm{~d} . \mathrm{m}$. In the last group of five locations, even several hundred times greater percentage amount of $\mathrm{Zn}$ was stated in the leaves. The largest amount of $\mathrm{Zn}$ was found in the Tanacetum vulgare leaves in Starachowice, where in comparison to Laczki, the $\mathrm{Zn}$ content was $1084,22 \%$ higher and the $\mathrm{Zn}$ concentration in this area was $312,753 \mathrm{mg} \cdot \mathrm{kg}^{-1} \mathrm{~d} . \mathrm{m}$.

In the research on and around the landfill site, the $\mathrm{Zn}$ content in tansy leaves was from $58.30 \mathrm{mg} \cdot \mathrm{kg}^{-1}$ d.m. to $721.90 \mathrm{mg} \cdot \mathrm{kg}^{-1} \mathrm{~d} . \mathrm{m}$. in the area where plants and soil had contact with wastes. In the areas isolated from the landfill and in the ones surrounding the landfill, the content of $\mathrm{Zn}$ in tansy leaves was from 82.71 to $131.60 \mathrm{mg} \cdot \mathrm{kg}^{-1} \mathrm{~d} . \mathrm{m}$. [Adamcova et

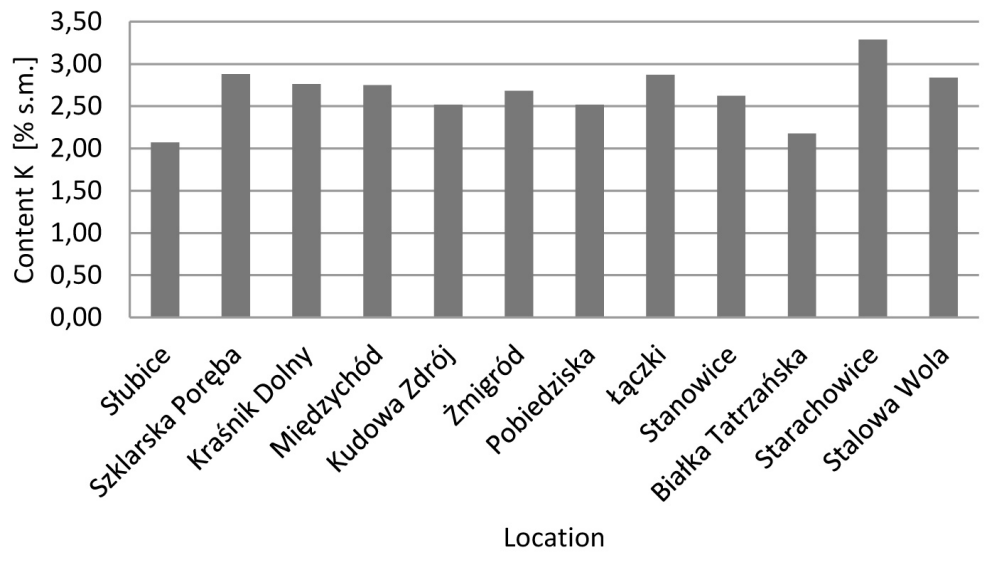

Figure 1. Content of $\mathrm{K}$ percentage in the tansy leaves (Tanacetum vulgare) from different positions. 


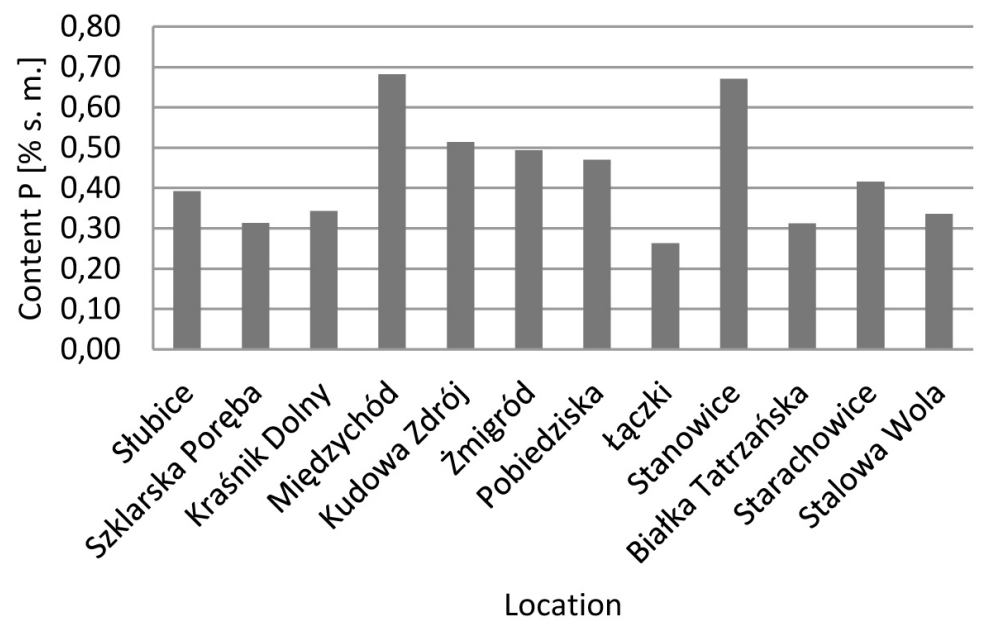

Figure 2. The content of P percentage in the tansy leaves Tanacetum vulgare) from different positions

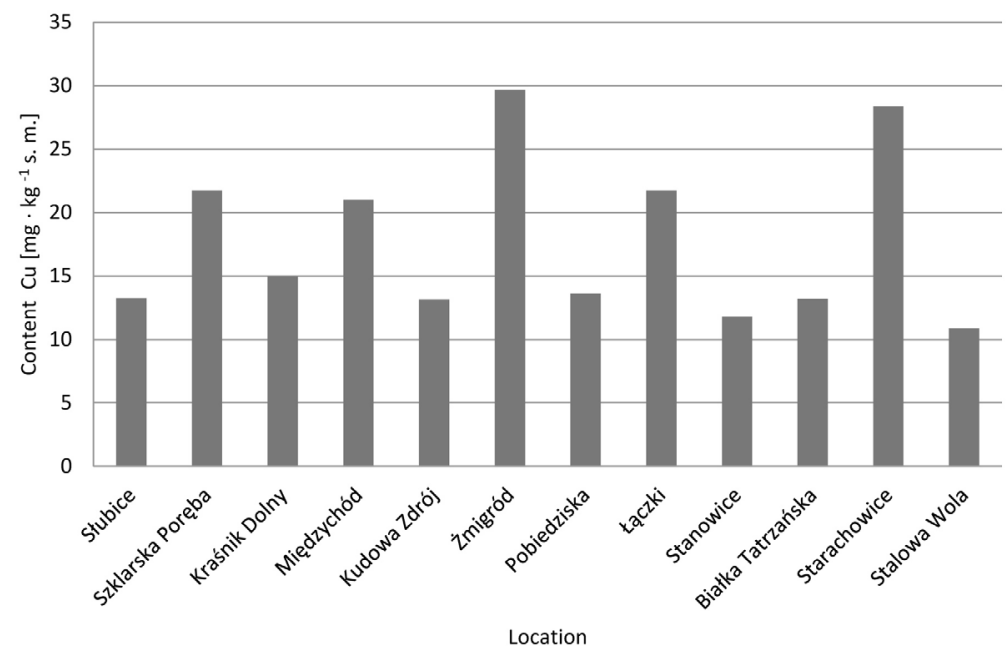

Figure 3. The content of $\mathrm{Cu} \mathrm{mg} \cdot \mathrm{kg}$ d.m in the tansy leaves Tanacetum vulgare from different positions

al. 2017]. In the studies carried out close to the opencast mine in Bełchatów, the Zn content in the Tanacetum vulgare leaves was from 125 to $178 \mathrm{mg} \cdot \mathrm{kg}^{-1}$ d.m. [Jasion et al. 2013]. The studies by Adamcova and Jasion both suggest a theory telling that the $\mathrm{Zn}$ concentration in tansy on the area used industrially undergoes significant changes, generated by the zinc access under various soil conditions [Adamcova et al. 2017].

In the Tanacetum vulgare leaves, a relatively small content of molybdenum was found, which in the case of seven positions was oscillating within the limits from $0.407 \mathrm{mg} \cdot \mathrm{kg}^{-1} \mathrm{~d} . \mathrm{m}$. in Łączki to 0.999 [mg $\mathrm{kg}^{-1} \mathrm{~d} . \mathrm{m}$.] in Pobiedziska. In the other five locations, a significant increase in the amount of molybdenum was observed and the highest Mo concentration $-2,015 \mathrm{mg} \cdot \mathrm{kg}^{-1} \mathrm{~d} . \mathrm{m}$. was noted in Kraśnik Dolny (Fig. 4).
The obtained Mo concentrations (Fig. 5) do not deviate from the element content in other plants (for example in the corn leaves (Zea mays) it is $1.17 \mathrm{mg} \cdot \mathrm{kg}^{-1} \mathrm{~d} . \mathrm{m}$. and allows for an appropriate plant growth [Fialho et al. 2013].

On the basis of the analysis concerning the average content of bio elements in the Tanacetum vulgare leaves, the influence of an environment type on the concentration of particular microelements was proven (Table 2). Along with the industrialisation increase, the average contents of $\mathrm{Cu}, \mathrm{Zn}$, and Mo rise as well. In the case of the studied metals, a positive correlation of zinc and copper was observed, which is additionally confirmed by other authors' results (Bednarek et al. 2008). As far as the studied macroelements and copper contents are concerned, no significant correlations were noted; however, in the case of zinc, a negative correlation with potassium was noted, 


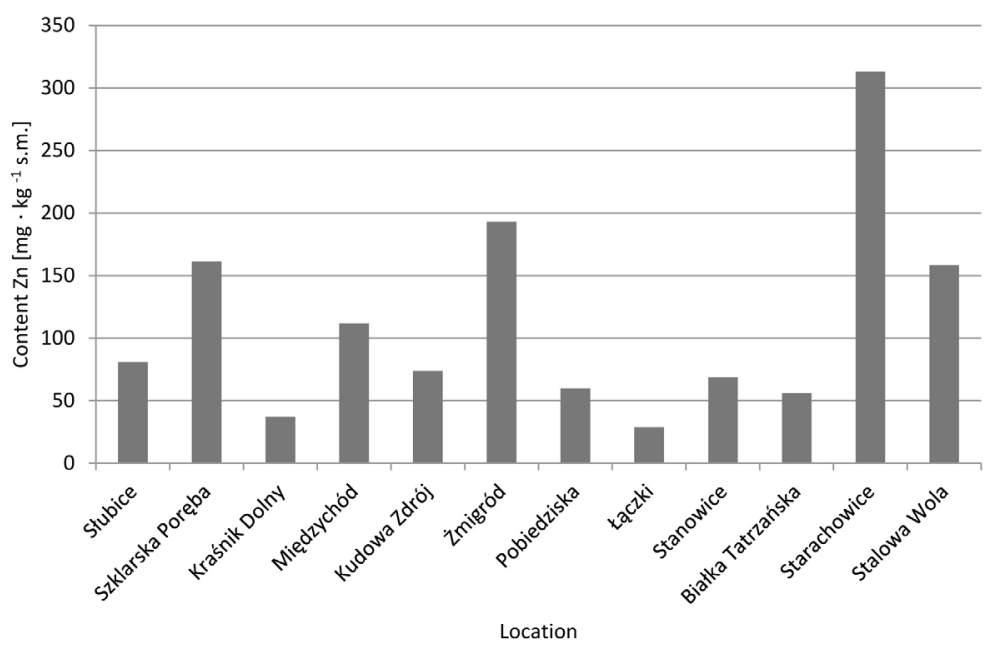

Figure 4. The $\mathrm{Zn}$ content [mg $\cdot \mathrm{kg}$ d.m.] in the tansy leaves Tanacetum vulgare from different positions

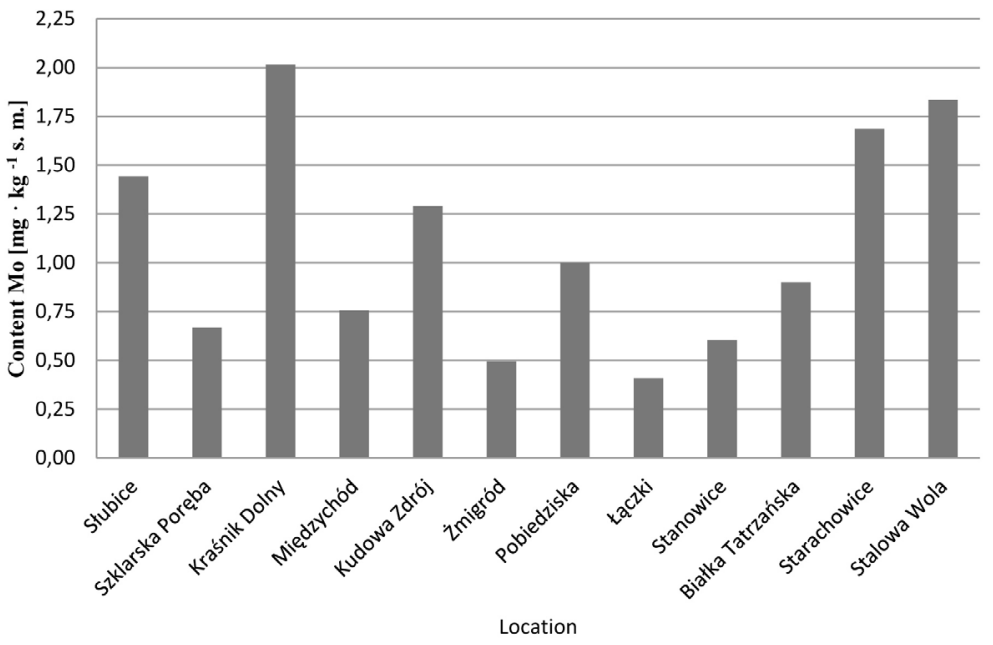

Figure 5. The Mo $\left[\mathrm{mg} \cdot \mathrm{kg}^{-1}\right.$ d.m.] content in the tansy leaves Tanacetum vulgare from different positions

a negative one for molybdenum with phosphorus, which may determine the process of incepting metallic elements from soil. Nevertheless, both the $\mathrm{P}$ and $\mathrm{K}$ contents were not influenced on the analysed area type ( $\mathrm{N}$ or $\mathrm{A})$.

\section{CONCLUSION}

The quantitative analysis shows the presence of different amounts of $\mathrm{K}, \mathrm{P}, \mathrm{Cu}, \mathrm{Zn}$ and $\mathrm{Mo}$ in the Tanacetum vulgare leaves on the anthropogenic and non-anthropogenic positions. High concentration of $\mathrm{Cu}, \mathrm{Zn}$, and $\mathrm{Mo}$ in the industrial sphere was strictly connected with the pollution caused by traffic and an industrial activity. The tansy that was picked up on both the anthropogenic as well as non-anthropogenic areas, was characterised by similar contents of $\mathrm{K}$ and $\mathrm{P}$ in its leaves, which indicates the lack of influence of the environment contamination level on the content of the metals in leaves.

The acquired and presented results included in the present study point at the usefulness of Tanacetum vulgare in monitoring the environment contamination with metals.

Table 2. The average content of bio elements in the Tanacetum vulgare leaves on the areas of anthropogenic (A) and non-anthropogenic (N) [mg $\left.\cdot \mathrm{kg}^{-1} \mathrm{~d} . \mathrm{m}.\right]$

\begin{tabular}{|c|c|c|c|c|c|}
\hline Type of area & $\mathrm{P}$ & $\mathrm{K}$ & $\mathrm{Cu}$ & $\mathrm{Zn}$ & Mo \\
\hline $\mathrm{A}$ & $4338(1639)$ & $26165(3676)$ & $18.17(8.38)$ & $175.2(101.2)$ & $1.20(0.65)$ \\
\hline $\mathrm{N}$ & $4338(1345)$ & $26895(3247)$ & $17.58(6.04)$ & $80.08(52.44)$ & $1.04(0.53)$ \\
\hline
\end{tabular}




\section{Acknowledgements}

The authors express their gratitude to the University Opole of Poland for the financing of the study, Institute of Pottery and Structural Materials for allowing us use the equipment and materials for this study.

\section{REFERENCES}

1. Adamcová D., Radziemska M., Ridošková A., Bartoň S., Pelcova P., Elbl J., Kynický J., Brtnický M., Vaverková M.D. 2017. Environmental assessment of the effects of a municipal landfill on the content and distribution of heavy metals in Tanacetum vulgare L. Chemosphere. 185. 1011 - 1018. doi: 10.1016/j.chemosphere.2017.07.060

2. Blagojevic P.D., Radulovic N.S., Skropeta D. 2015. Chemotaxonomic implications of postharvest/storage-induced changes in plant volatile profiles - the case of Artemisia absinthium L. essential oil. Chemistry \& Biodiversity. 12. $1237-1255$. doi: $10.1002 / \mathrm{cbdv} .201400288$

3. Chaplygin V., Minkina T., Mandzhieva S., Burachevskaya M., Sushkova S., Poluektov E., Antonenko E., Kumacheva V. 2018. The effect of technogenic emissions on the heavy metals accumulation by herbaceous plants. Environ Monit Assess. 190(3). doi: 10.1007/s10661-018-6489-6

4. Coté H., Boucher M.A., Pichette A., Legault J. 2017. Anti-Inflammatory, Antioxidant, Antibiotic, and Cytotoxic Activities of Tanacetum vulgare L. Essential Oil and Its Constituents. Medicines, 4, 34. doi: 10.3390/medicines4020034

5. Derda M., Hadaś E., Thiem B., Wojt W.J., Wojtkowiak-Giera A., Cholewiński M., Skrzypczak Ł.. 2012. Tanacetum vulgare L. as a plant with potential medicinal properties for Acanthamoeba keratitis. Nowiny Lekarskie. 6 (81). 620-625. ISSN 0860-7397. (in Polish).

6. Devrnja N., Anđelković B., Aranđelović S., Radulović S., Soković M., Krstić-Milošević D., Ristić M, Ćalić D. 2017. Comparative studies on the antimicrobial and cytotoxic activities of Tanacetum vulgare L. essential oil and methanol extracts. South African Journal of Botany. 111. 212-221. doi:10.1016/j.sajb.2017.03.028.

7. Goudarzi T., Saharkhiz M.J., Rowshan V. 2015. Ontogenetic variation of essential oil content andconstituents in tansy (Tanacetum vulgare L.). Journal of Applied Research on Medicinal and Aromatic Plants. 2. 48-53. doi: 10.1016/j.jarmap.2015.03.003

8. Grela E.R., Dzida K. 2001. Wpływ środowiska na zawartość składników mineralnych w wybranych ziołach. Annales UMCS sec. EEE vol. IX, 159-165.
9. Halicioglu, O., Astarcioglu, G., Yaprak, I., Aydinlioglu, H. 2011. Toxicity of Salvia officinalis in a newborn and a child: an alarming report. Pediatr. Neurol. 45, 259-260. doi: 10.1016/j.pediatrneurol.2011.05.012

10. Héthelyi E., Tétényi P., Kettenes-van den Bosch J.J., Salemink C.A., Heerma W., Versluis C., Kloosterman J., Sipma G. 1981. Essential oils of five Tanacetum vulgare genotypes. Phytochemistry, 20(8), 2847-1850. DOI: 10.1016/0031-9422(81)84018-6

11. Jasion M., Samecka-Cymerman A., Kolon K., Kempers A.J. 2013. Tanacetum vulgare as a Bioindicator of Trace - Metal Contamination: Study of a Naturally Colonized Open - Pit Lignite Mine. Archives of Environmental Contamination and Toxicology. 65, 442-448. DOI 10.1007/ s00244-013-9922-4.

12. Kashin, V.K., \& Ubugunov, L.L. 2012. Accumulation features of microelements in the grain of wheat grown in Western Transbaikalia. Agrokimiya, 4, 68-76.

13. Kęsik T., Wojciechowska A. E, Pitura K. (2008). Differentiation of morphological traits of common tansy (Tanacetum vulgare 1.) originating from different stands. Acta Agrobotanica. vol. 61 (2). 189-194

14. Lahlou, S., Tangi K.C., Lyoussi B., Morel N. (2008). Vascular effects of Tanacetum vulgare L. leaf extract: In vitro pharmacological study. Journal of Ethnopharmacology. 120. 98 - 102. doi : 10.1016/j.jep.2008.07.041

15. Lityński T., Jurkowska H. (1982). Żyzność gleby i odżywianie się roślin, PWN Warszawa, 298 - 305. (in Polish)

16. Lucimar L. Fialho, Joaquim A. Nóbrega, Jenny A. Oviedo. (2013). Determination of molybdenum in plants by vortex-assisted emulsification solidified floating organic drop microextraction and flame atomic absorption spectrometry. Spectrochimica Acta Part B. 86. 142-145. Doi: 10.1016/j. sab.2013.02.005

17. Marques, A. P. G. C., Rangel, A. O. S. S., \& Castro, P. M. L. (2009). Remediation of heavy metal contaminated soils: phytoremediation as a potentially promising clean-up technology. Critical Reviews in Environmental Science and Technology, 39(8), 622-654. doi:10.1080/10643380701798272

18. Mitich L.W., (1992). Intriguing world of weeds: tansy. Weed Technology. 6 (1). 242-244.

19. Mehrparvar M., Zytynska S. E., Balog A., Weisser W. W. (2018). Coexistence through mutualist - dependent reversal of competitive hierarchies. Ecology and Evolution.8.1247-1259. doi: 10.1002/ece3.3689

20. Motuzova, G. V.,Minkina, T.M., Karpova, E. A., Barsova, N. U., Mandzhieva, S. S. (2014). Soil contamination with heavy metals as a potential and real risk to the environment. Jour- 
nal of Geochemical Exploration, 144, 241-246. doi: 10.1016/j.gexplo.2014.01.026

21. Móricz Á. M., Häbe T. T., Böszörményi A., Ott P. G., Morlock G. E. (2015). Tracking and identification of antibacterial components in theessential oil of Tanacetum vulgare L. by the combination ofhigh-performance thin-layer chromatography with directbioautography and mass spectrometry. Journal of Chromatography A, 1422. 310-317. doi: 10.1016/j.chroma.2015.10.010

22. Özbilgin S., Akkol E. K., Ergene Öz B., Ilhan M., Saltan G., Acıkara Ö. B., Tekin M., Keleş H., Süntar I. (2018). In vivo activity assessment of some Tanacetum species used as traditional wound healer along with identification of the phytochemical profile by a new validated HPLC method. Iran J Basic Med Sci. 21. 145 - 152. doi: 10.22038/ IJBMS.2018.24258.6055

23. Qi X., Wang H., Song A., Jiang J., Chen S., Chen F. (2018). Genomic and transcriptomic alterations following intergeneric hybridization and polyploidization in the Chrysanthemum nankingense $\times$ Tanacetum vulgare hybrid and allopolyploid (Asteraceae). Horticulture Research. Vol. 5 (1). Published online 2018 Feb 7. doi: 10.1038/ s41438-017-0003-0
24. White, P. J., Brown, P. H. (2010). Plant nutrition for sustainable development and global health. Annals of Botany, 105(7), 1073-1080. Doi: 10.1093/ $\mathrm{aob} / \mathrm{mcq} 085$

25. Wierzchowska-Renke K., Ivancheva S., Kurteva M., (1997). Effect of environment pollution on the composition of polyphenols and bioelements content in Achillea millefolium L. and Tanacetum vulgare L. HERBA POLONICA. XLIII, 4, 412-415. ISSN: $0018-0599$.

26. Wojciechowska A. E. (2008). The kontent of mineral elements in Tanacetum vulgare L. from different habitats. Annales OMCS Sectio EEE Horticultura. Vol. XVIII (3). 10 - 16. ISSN 1233 - 2127.

27. Wolf V. C., Gassmann A., Clasen B. M., Smith A. G., Müller C. (2012). Genetic and chemical variation of Tanacetum vulgare in plants of native and invasive origin. Biological Control. 61. 240-245. Doi: :10.1016/j.biocontrol.2012.01.009

28. Zaurov, D.E., Belolipov, I.V., Kurmukov, A.G., Sodombekov, I.S., Akimaliev, A.A., Eisenman, S.W. (2013). The medicinal plants of Uzbekistan and Kyrgyzstan. In: Eisenman, S.W., Zaurov, D.E., Struwe, L. (Eds.), Medicinal Plants of Central Asia: Uzbekistan and Kyrgyzstan. Springer, New York, 235. 